\title{
Cheilitisek differenciál-diagnosztikája
}

\section{The differential diagnosis of cheilitis}

\section{NÉMETH ZSOLT DR. ${ }^{1}$, HOLLÓ PÉTER DR. ${ }^{2}$, PÓNYAI GYÖRGYI DR. ${ }^{2}$, BARABÁS JÓZSEF DR. ${ }^{1}$, BOGDÁN SÁNDOR DR. ${ }^{1}$}

\author{
Semmelweis Egyetem, Fogorvostudományi Kar, Arc-Állcsont-Szájsebészeti és \\ Fogászati Klinika ${ }^{1}$ \\ Semmelweis Egyetem, Általános Orvostudományi Kar \\ Bôr-, Nemikórtani és Bőronkológiai Klinika²
}

\section{ÖSSZEFOGLALÁS}

Az ajkak börének gyulladásos elváltozásai igen gyakori panaszként jelentkeznek, hátterükben igen változatos kórképeket kell elkülöníteni. Szerzók a leggyakoribb, alábbi kórképeket tekintik át: cheilitis actinica, cheilitis glandularis, cheilitis granulomatosa (Miescher-Melkersson-Rosenthal szindróma), cheilitis chronica abrasiva praecancerosa, lupus erythematosus orális manifesztációi, atópiás és allergiás kontakt cheilitis. A cheilitisek több formája prekancerózus állapot, belólük laphámrák alakulhat ki. Prediszponáló faktorok: erôs, tartós UVA-UVB sugárzás, dohányzás, rossz szájhygiene, világos börszín, krónikus ajakgyulladás. Az expozíció fennállásának idejével arányosan, évról évre nö a diszplázia és a malignus tumor kialakulásának veszélye. Cheilitis glandularis, cheilitis actinica klinikai diagnózisának pillanatában az esetek mintegy 18-35\%-ban már szövettannal igazolható carcinoma in situ, laphámrák alakult ki. A cheilitises betegek 10-20\%-ánál bizonyítható atópiás hajlam, az allergiás kontakt cheilitis hátterében releváns allergének: illatanyagok, a perubalzsam és a nikkel állhat. Ezeket elsösorban arc- és szájápolók, szájhigiénés termékek, dekorkozmetikumok, ritkán élelmiszerek tartalmazzák. A malignus transzformáció esélyének felméréséhez, a hatékony kezeléshez elengedhetetlen a pontos diagnózis, differenciáldiagnózis. Ennek felállításához leggyakrabban elegendő a klinikai tünetek alapos értékelése, a hisztopatológiai kép valamint a direkt immunfluoreszcens vizsgálatok. A kezelés sokszor elhúzódó és eredménytelen, igy a megelözés áll elötérben. A hatékony terápia részei. fényvédő, hidratáló, zsíros kenöcsök, retinoidok, lokális szteroidok, immun-modulánsok, antihisztaminok, antibiotikumok, antifungális szerek. Terápiarezisztens prémalignus, malignus léziók esetén sebészi megoldás jön szóba.

Kulcsszavak: cheilitis - cheilitisek differenciáldiagnosztikája - ajakrák

\section{SUMMARY}

Inflammatory processes of the lips present as common problems. In the background various pathologies are to be identified. In the present article the following pathologies are reviewed: actinic cheilitis, glandular cheilitis, granulomatous cheilitis (Miescher-Melkersson-Rosenthal syndrome), chronic abrasive cheilitis, oral manifestations of lupus erythematodes, atopic and contact cheilitis.

Several forms of cheilitis are precancerous lesions, which may develop into squamous cell carcinoma. Predisposing factors: strong and lasting UVA-UVB radiation, smoking, bad oral hygiene, light skin, chronic cheilitis. The risk of dysplasia or developing a malignant tumour rises year by year in direct relation to the time of exposure. Upon diagnosis of glandular cheilitis or actinic cheilitis, a histologically malignant tumour is already present in 18-35 per cent of the cases. There is an atopic tendency in 10-20 per cent of patients with cheilitis. Relevant allergens related to contact cheilitis: fragrant substances, peruvian balm and nickel. These are mainly contained by face and mouth care products, oral hygiene products, cosmetic products and rarely alimentary products. Exact diagnosis and differential diagnosis is absolutely necessary for the identification and efficient treatment of malignant transformation. The thorough evaluation of clinical signs and symptoms, histological testing and direct immunofluorescence are mostly sufficient to achieve diagnosis. Treatment is often lengthy and inefficient, thus prevention should be the prime objective. Efficient therapies include: sunscreen, moisturising and greasy creams, retinoids, local steroids, immunomodulants, antihistamines, antibiotics, antifungals. Premalignant lesions resistant to therapy, as well as malignant lesions are mostly treated surgically.

\section{Key words: Cheilitis - differentialdiagnosis - lip cancer}

Levelező szerző: Dr. Németh Zsolt PhD, egyetemi docens, Semmelweis Egyetem, Fogorvostudományi Kar Arc-Állcsont-Szájsebészeti és Fogászati Klinika, 1085 Budapest, Mária u. 52. E-mail: nemethzs@fok.usn.hu 
Bár a macrocheiliát, mint tünetet Cornelius Stalpart Van der Wiel már 1687-ben említi, először (5 esetről beszámolva) Richard von Volkmann írta le 1870-ben, az alsó ajak kis nyálmirigyeit érintố mukopurulens gyulladást (75), mely a nyálmirigyek kivezetőcsöveinek tágulatával, az ajakpír lobos folyamatával járt együtt. Ezt követően több szerző, számos esetról számolt be, ahol az alsó ajak megnagyobbodott, a nyálmirigyek kivezetô-pontjai kiemelkedtek és különböző fokú, kiterjedésû́ gyulladás volt megfigyelhetô.

Számos elnevezése ismert attól függően, hogy melyik stádiumban tart az elváltozás, illetve ki volt a kórforma leírója.

Ebben az értelemben az alábbi formákat említjük: Volkmann-cheilitis, myxadenitis labialis, Baelz-, Puente-szindróma (50), cheilitis glandularis simplex, cheilitis glandularis suppurativa, cheilitis glandularis apostematosa).

Az ajkakat érô UV- sugárzás kumulatív dózisa felelôs a cheilitis actinica kialakulásáért. Számos szerző véleménye, hogy cheilitis actinica cheilitis glandularis talaján fejlődik ki és nem fordítva.

A cheilitisek etiológiája, tünettana, differenciáldiagnózisa igen szerteágazó, a folyamat kialakulásának megértéséhez szükség van az ajak-elváltozások patológiai hátterének alapos ismeretére is.

\section{Cheilitis glandularis}

\section{Epidemiológia}

Férfiaknál és nôknél egyaránt, bármely életkorban előfordulhat, a férfi:nô arány 2-3:1 (53). Elsôsorban középkorú (40-50 év közötti) férfiakon látjuk (80). Világviszonylatban nem figyeltek meg földrész- vagy országspecifikus megoszlást, úgy tûnik azonban, hogy világos bőrû (különösen albino) egyéneknél gyakoribb $(34,46)$. Fiataloknál, gyermekeknél is leírták (83).

\section{Etiológia}

Kóroki tényezôként az erôs napfény (UV sugárzás) emelendő ki első helyen. Úgy tartják, hogy idült cheilitis glandularis talaján cheilitis actinica (cheilitis solaris) alakulhat ki, mely már „elôkapuja” az alsó ajak laphám-karcinómájának $(8,36)$.

Az ajakrák elsôsorban a tûző napon dolgozó földmúvesek, tengerészek, halászok, magashegyi körülmények között élők, sportolók betegsége.

Más hatások, így mechanikai irritáció, az ajak harapdálása, a dohány minden formában történő fogyasztása, gyulladás, elégtelen szájhigéne, pszihés tényezők, szájlégzés, mind-mind szerepelhetnek kiváltó faktorként (7).

Egyes szerzók felvetették, hogy autoszomális, domináns módon öröklődő betegségről lehet szó. Parmar és Muranjan olyan kórképet (szindrómát) ismertetett, melynek tünetei többek között: az ajak kettôzöttsége (double lip), ptosis, pszichés eltérések $(12,48)$. Az örökletes jelleg mellett jelenleg egyetlen, nagy beteganyagot feldolgozó, klinikai esettanulmány sem szól.

Az évek során a tünetek állandósulnak, a folyamat krónikussá válik.

\section{Klinikum}

A cheilitis glandularis krónikus, progresszív megbetegedés, a betegek többsége 3-12 hónapja tartó panaszokkal jelentkezik. Elsősorban férfiakon, (70-90\%-ban) az alsó ajak megbetegedése (44), de leírtak, gyermekeken és a felső ajkon (4\%) kialakult kórképet is $(64,77,80,83)$.

Lourenco és mtsai. szimultán, alsó és felsőajak (34), Lederman mindkét ajak (17-30\%) és a buccák (30), míg mások kizárólag a felső ajkon, Williams pedig a palatumon elhelyezkedő kórformákról tesznek említést. Utóbbi szerzők az ajkakon kívül kialakuló, krónikus kisnyálmirigyek gyulladásával együtt járó, hasonló klinikai és hisztológiai tüneteket mutató elváltozásokat „,stomatitis glandularisnak" nevezik (79).

A krónikus gyulladás eredményeként az ajak kötőszövet-állománya felszaporodik. Az ajakpír megvastagszik, fájdalmas berepedések, ezek talaján kisebb-nagyobb, olykor egymással összefolyó fekélyek alakulnak ki. Az ajak tömegessé, tömött tapintatúvá válik, kifordul, ún. macrocheilia alakul ki.

A klinikai tünetek elôterében az ajak duzzanata, a fekélyképződés, pörkösödés, kisnyálmirigy-hiperplázia, tályogképződés állnak. A mirigyek gyulladtak, nodulárisan megnagyobbodnak, kivezetôcsöveik tágultak, a kivezetôpontok az ajakpír felszínéról enyhén kiemelkednek, de centrumuk behúzódik, ekörül hyperémiás udvar helyezkedik el (52). Első látásra úgy tûnik, minta az alsó ajak pírján vörös pontocskák lennének. A kivezetőcsövekból kezdetben viszkózus, transzparens nyál (mucin) ürül, illetve préselhetô ki. Szuppuratív formában ez a váladék mukopurulens jelleget ölt.

A bőrön kóros pigmentáció alakul ki, a hám tömötté, felszíne érdessé válik, fokozott szarusodást mutat.

A cheilitis glandularis lefolyásában három stádium különböztethetố meg (korábban ezeket a formákat külön-külön betegségnek tartották) $(62,77,80)$ :

a.) Cheilitis glandularis simplex: kezdeti szak, csak a piros, fájdalmatlan, az ajakpíron vörös vagy sötét pontozottság észlelhető (leírójuk Puente és Acevedo).

b.) Cheilitis glandularis suppurativa superficialis, Baelzbetegség: fájdalmatlan ajakduzzanat, fekély- pörkképződés jellemzi, az ajak tömött tapintatú.

c.) Cheilitis glandularis suppurativa profunda seu apostematosa (von Volkmann) seu myxadenitis labialis: Fôként staphylococcus törzsek okozta, tályogképződéssel járó folyamat, az ajkon többszörös fisztulaképzôdés figyelhetô meg, mely kiterjedt hegesedéssel jár.

A berepedések, fekélyek égó fájdalmat okoznak, váladékoznak. Ez a váladék pörköt képez, mely ha leválik, vérzés indul.

\section{Malignizáció}

Az ajakrák kialakulását legtöbbször krónikus ajakgyulladás (cheilitis glandularis, cheilitis actinica) előzi meg. A legtöbb esetben nyilvánvaló a felszíni hám premalignus diszpláziája, sôt (a különböző közlemények szerint) a krónikus gyulladás talaján, már a diagnózis 
pillanatában, az esetek mintegy 18-35\%-ban valós laphámrák alakult ki.

A folyamat fennállásának idejével arányosan, évről évre nô a diszplázia és a malignus tumor kialakulásának veszélye (76). A fokozódó macrocheilia miatt ugyanis az alsó ajak egyre jobban kifordul (evertálódik), így a védtelen mucosa sokkal jobban ki van téve a napsugárzás káros hatásának.

Rosszindulatú elfajulás szempontjából a cheilitis glandularis suppurativa superficialis és profunda képezik a legnagyobb rizikójú eseteket.

\section{Diagnosztika}

Stoopler és munkatársai cheilitis glandularis kapcsán, cystadenoma papillare-szerû, ductalis terjedésről számolnak be, periduktális, krónikus gyulladást (dochitis), hegképződést, krónikus szklerotizáló sialoadenitist írnak le (70). Musa a cheilitis glandularis generalizált formáját említi, ő a „suppurativ stomatitis glandularis” kifejezést használta (42). Leao HIV-fertőzött beteg kisnyálmirigydiszfunkcióját említi, melynek talaján exfoliatív cheilitis keletkezett (29). Ez utóbbi igen jellemző tünet (akár még nem diagnosztizált) HIV-pozitív egyéneknél (5).

Szövettanilag az eltérés nélküli, érett hámtól, az enyhe, közepes vagy súlyos diszplázián át, a már kifejlett laphámrákig, minden előfordulhat. Amennyiben bazofil kollagén-degeneráció (elastosis solaris) van jelen, úgy inkább cheilitis actinica a diagnózis.

Cheilitis glandularis esetén a stróma ödémája, hiperémia, a felszíni hám hiperkeratózisa, erózió, ulceráció figyelhetố meg. A hámszövet lamina propriája mentén limfocitás infiltráció, a mirigykamrákban intersticiális gyulladás, fibrózis látható. Az ajakban található kisnyálmirigyek tágult kivezetôcsöveibôl sûrû nyál exprimálható, mely az ajakhoz tapadva, kellemetlen panaszt okoz a betegnek.

\section{Differenciáldiagnosztika}

Macrocheiliát okozhat még: mucokele, sialoadenitis chronica, a kis nyálmirigyeket érintő nyálkövesség, herpes simplex recurrens, haemangioma, sérülés után visszamaradt, szervült vérrög, lymphangioma, neurofibromatosis, lepra, TBC, angioneurotikus oedema, cheilitis granulomatosa (Miescher-Melkersson-Rosenthal szindróma), szisztémás-granulomatózus betegségek (sarcoidosis gyanúja esetén biopszia szükséges). Macrocheilia alakulhat ki malignus folyamatok (mesenchymális tumorok, lymphoma, cystadenoma, cystadenocarcinoma, mucoepidermoid carcinoma) kapcsán is. Tisztázni szükséges, hogy Crohnbetegség, colitis ulcerosa nem áll-e a háttérben.

A cheilitis glandularis az alábbi kórképektôl kell még elkülöníteni: lupus erythematosus, mucokele, cisztás fibrózis, az ajakpír égési sérülései (nap, forró folyadék), cheilitis actinica, cheilitis angularis, elephantiasis, atópiás (ekcémás) cheilitis; szájlégzés, szél, gyógyszer okozta xerosztómia, Sjögren-szindróma (szintén biopszia szükséges!), HIV-infekció talaján kialakult kisnyálmirigy-funkciózavar.

\section{Kezelés}

Legfontosabb a cheilitist kiváltó, irritáló tényezők kiküszöbölése, fényvédő krémek használata, az erôs, tűzô napsugárzás kerülése.

Az ödéma csökkentésére (nem-purulens folyamatoknál) antihisztaminokat adhatunk.

A folyamat bakteriálisan felülfertőződhet, ilyenkor mikrobiológiai vizsgálat, célzott antibiotikus kezelés indokolt (20). Noduláris típusú cheilitis glandularis esetén a konkomittáló lokális, intralézionálisan adott, vagy szisztémás szteroid-kezelés potencírozhatja az antibiotikum hatását, azonban hosszan tartó vagy magas dózisú szteroid-kezelés önmagában is okozhat fibrózist, hegesedést.

Lokális, 0.1\%-os, tacrolimus tartalmú kenốccsel, 5-FUval végzett helyi kezelés is eredményes lehet $(4,14,17$, 84).

A folyamat olykor candidiasissal társulhat, illetve felülfertőződhet, ebben az esetben antifungális kezelés indokolt. Gondolni kell arra, hogy a gomba megjelenése lehet az immunrendszert gyengítő fertőzés (HIV), hosszan tartó antibiotikus vagy szteroid-kezelés eredménye is.

Amennyiben konzervatív kezelésre a tünetek nem enyhülnek, fekélyes területek alakulnak ki, a sebészi megoldást (lineáris-, kvadrátexcízió, ajakplasztika) választjuk. Az ajakpír kimetszése útján eltávolítjuk a napsugárzás által károsított területet és egyben redukálhatjuk a macrocheiliát is. Egyes szerzők krioterápia esetén számoltak be kedvező eredményekrôl (22).

\section{Cheilitis actinica}

\section{Epidemiológia}

Hasonlóan a cheilitis glandularisnál leírtakhoz, a kórkép elsősorban építőipari, mezőgazdasági munkásokat, magaslaton, a trópusokon élőket, hegymászókat, síelőket, vízi sportokat ûzőket, halászokat, tengerészeket érinti (21). A férfi:nő arány itt 12:1.

Főként középkorú, világos bőrú egyéneket érint. Kifejlődésében döntő, hogy az ajak hámjában kevés, protektív hatású melanocita található, a keratinizált hám igen vékony (37).

\section{Etiológia}

Prediszponáló etiológiai faktorok: napfény okozta krónikus irritáció, dohányzás, rossz szájhygiene. Az ajak krónikus gyulladása (pl. HPV-kontamináció, cheilitis glandularis) sejtszintú, genetikai károsodás révén a cheilitis actinica malignus transzformációját eredményezheti (10).

Az UV-sugárzás hullámhossz-tartománya 100 és 400 nm közé esik (UV-A=320-400 nm, UV-B=290-320 nm, UV-C=100-290nm). Az UV-C sugárzást a Föld légköre gyakorlatilag teljes egészében kiszúri. Az UV-A és UV-B sugárzás (kollagén károsítás, A-vitamin lebontás, lokális immunszuppresszió, ionizáció útján) „öregíti”, károsítja a bőrt $(39,74)$. Az ionizáció hidroxil és oxigén gyököket eredményez, így, indirekt úton a keratinociták DNS-állományának epigenetikai és genetikai károsodását okozza. Ma úgy túnik, hogy a keratosis solaris (bőr) és a cheilitis 
actinica kifejlődéséért elsôsorban az atmoszféra által csak részben kiszûrt UV-B sugárzás felelős (81).

Bizonyítékokkal rendelkezünk arról, hogy az UV-B sugárzásnak nem csupán iniciatív szerepe van a hámsejtek genetikai károsodásában, de promotálja a transzformált sejtek expanzióját is, így malignus daganat kialakulását segíti elő (31).

Az UVB képes a P53 szuppresszor gén mutálására, így a sejtciklus elégtelen szabályozása révén genetikai instabilitást, a transzformált keratinociták felszaporodását okozza.

\section{Klinikum}

Az esetek 90\%-ában az alsó ajak érintett (56), a felsô lényegesen ritkábban (49). Az UV-sugárzás irritáló hatására az ajak felszíni hámja megvastagszik, kiszárad, színe szürkésfehér lesz, berepedezik, mély fisszúrák keletkeznek. Az ajakpír hámlik, olykor hiperkeratotikus, ulcerált, fájdalmas, fekélyek tarkítják. A felszín néha atrófiás, rajta keratózis, rhagadok láthatóak. A fekélyek felszínén pörk keletkezik, ha ez leválik, vérzést tapasztalunk.

A panaszos anamnesztikus idố viszonylag hosszú, átlagosan 2.6 év.

A krónikus UV-sugárzás hatására az ajakpír keratinocitái molekuláris és genetikai változáson mennek keresztül. Ma azt gondoljuk, hogy a cheilitis actinica ezen módosult keratinociták expanzióját jelenti $(11,44)$. Szövettani vizsgálatkor, emelkedett mitotikus ráta, nukleáris atípia (pl. hiperkromázia), a keratinociták szabálytalan elrendeződése figyelhetô meg a hám bazális részén.

Cheilitis actinicá-ban szenvedő betegek gyakran megnyalják az alsó ajkukat. Ez kettős célt szolgál: egyrészről megnedvesítik, a kellemetlen érzést okozó, kiszáradt ajakpírt; másrészrôl csökkentik a pörk keménységét, mely ha így válik le, nem okoz olyan gyakran vérzést.

Csökkenhet a szájnyitás mértéke, a szájszélen olykor vezikulák jelennek meg. A beteg étvágytalan, testsúlya csökken.

Cheilitis actinica acuta keletkezik nap okozta leégés hatására, legtöbbször fiatal egyéneknél. Az ajak duzzadt, ödémás, felszíne vörös, gyors hólyagképződés is jellemezheti.

Szövettanilag akantózis, hiperkeratózis, parakeratózis, nem-specifikus, felszínes limfocitás-hisztiocitás infiltráció figyelhető meg.

Kezelése hûtésből, antihisztaminok, lokális szteroidok adásából áll. Az ajak felszínét chlorhexidinnel fertőtleníthetjük.

Cheilitis actinica chronica esetén a klinikai képet a keratotikus ajakpír uralja, hisztológiai megjelenése hasonlatos az akut formához. Talaján, hosszú fennállás során, laphámrák alakulhat ki. A hosszú, napfény-expozíciós idô káros alterációi kumulálódnak és a szöveteket irreverzibilis károsodás éri. Az esetek mintegy 72\%-ában már az első jelentkezés pillanatában közepes fokú diszplázia és/vagy invazív karcinóma áll fenn. A malignitás gyanúját erósíti az induráltság, a fekélyképződés, a perzisztáló eritéma, hiperkeratotikus területek jelenléte. Mindezen elvál- tozások biopsziát, a legtöbb esetben a képlet in toto excízióját indokolják (37).

\section{Malignizáció}

A diszplázia, az elastosis solaris (a hám alatti kötőszövet bazofil degenerációja), a gyulladás, vazodilatáció a betegek mindegyikében jelen van, míg a hiperplázia, a hiperkeratózis vagy az atrófia 55-86\%-ban figyelhetó meg (9). Fentiek miatt a cheilitis actinica több szerző szerint intraepiteliális, in situ neopláziának felel meg $(44,55)$.

\section{Differenciáldiagnózis}

Elsősorban az ajkat érintő lichen ruber planustól, planocelluláris ráktól, pemphigus vulgaristól, dermatitisztől, keratosis solaristól kell elkülöníteni.

Cheilitis actinica talaján kialakul laphámkarcinóma az esetek 11\%-ában ad áttétet, míg keratosis solaris esetén ugyanez az érték mindösszesen $1 \%(35,54,59)$.

\section{Kezelés}

A legfontosabb a megelőzés, a veszélyeztetett (világos bőrű, dohányzó, középkorú, férfiak) délelőtt 10 és délután 14 óra körül kerüljék az arcukat érő, direkt napsugárzást, használjanak fényvédő krémeket. A káros UV-sugárzás elleni védekezést korai gyermekkorban kell elkezdeni és élethosszig folytatni. Védőruházat (pl. sapka, szalmakalap), a déli órákban a napsugarak kerülése, fényvédő krémek használata javasolt $(31,63)$. Ugyanez vonatkozik olyan betegekre, akiknél a cheilitis actinica akár enyhe formája már jelentkezett. A terápia kiválasztásához alapvetően fontos az anamnézis pontos ismerete, a betegek alapos vizsgálata. Egészen másként kezelünk egy UV-behatásnak alig kitett irodai dolgozót és egy, tartósan a napon tartózkodó (dolgozó, sportoló) egyént.

A kezelést a panaszok enyhítése és a malignus transzformáció megelőzése indokolja. A károsító-kiváltó, irritatív faktorok kizárása elsôrendû. Enyhe formáiban (a keratózis nem túl pregnáns), helyileg alkalmazott retinoidokat, puhító, fényvédő, zsíros kenőcsöket alkalmazunk. Súlyosabb esetben hialuronsav-gél (2.5\%) (32), 5-FU tartalmú kenôcs/gél, triklórecetsavas hámlasztás, fotodinámiás kezelés (2) használhat. Az NSAID-készítményeknek bizonyos mértékben antineoplasztikus hatásuk is van. A daganatszövetben fokozott mértékben expresszálódó ciklooxigenázokat (COX-1 és COX-2) bénító tulajdonságuknál fogva, apoptózist idéznek elő (15).

Ulcerált, daganatra gyanús képletek megjelenése esetén sebészi megoldás, $\mathrm{CO}_{2}$ vagy Er:YAG lézer-vaporizáció, lézer-exstirpatio $(1,47,60,69,85)$, lineáris excízió, kvadrát-excízió, ajakplasztika (56), krioterápia (22), dermabrázió (13) választandó.

\section{Cheilitis chronica abrasiva praecancerosa}

Ha cheilitis actinica chronica fennállása esetén jelentős az erodált területek aránya, akkor cheilitis abrasiva praecancerosa keletkezhet. Az erózió és az induráció együttes 
fennállása esetén a legvalószínúbb a rosszindulatú folyamat kialakulása.

Ha cheilitis chronica abrasiva praecancerosa talaján alakul ki karcinóma, úgy a beteget még a szokásosnál is szigorúbban kell ellenőrizni, mivel ebben az esetben igen magas a lokálrecidívák és a nyaki áttétek előfordulásának valószínúsége.

\section{Cheilitis granulomatosa (Miescher-Melkersson-Rosenthal szindróma)}

Ritka betegség, az ajak megvastagodását granulomatózus gyulladás okozza, tágabb értelemben az orofaciális granulomatózisok közé tartozik. Miescher-féle cheilitisrôl beszélünk, ha a tünetek (granulomatózis) csak az ajakra korlátozódnak. Egyesek a Melkersson-Rosenthal szindróma monoszimptomatikus formájának tartják. MelkerssonRosenthal szindróma esetén faciálparézis és barázdált nyelv is megfigyelhetô.

A Melkersson-Rosenthal szindróma esetenként a Crohn-betegség $(16,27,43,65,78)$, sarcoidosis (3) vagy az orofaciális granulomatózis orális manifesztációja képében jelentkezhet.

\section{Etiológia - Epidemiológia}

Kóreredete ismeretlen, a genetikai hajlamot illetően történtek megfigyelések, ezeket ikertestvérekben kialakult kórképekkel, egyebekben tünetmentes hozzátartozókban megfigyelt, plikált nyelv jelenlétével magyarázzák (72). Nemek és etnikumok tekintetében nem találtak bizonyított eltérést, elsősorban fiatal felnőttek betegsége. Az ételekben található antigének gyakran állnak orofaciális granulomatózis hátterében. Kontakt allergének (arany, ólom, kobalt) etiológiai szerepére is találunk adatot $(40,41,82)$.

\section{Klinikum}

Klinikailag először ismétlődő, ödémaszerû duzzanat jelenik meg egyik, vagy mindkét ajakban, olykor a szem körül, ez pár óra, esetleg pár nap alatt leapad. Gyakori ismétlődés mellett az oedema perzisztál, lázas állapotok, fejfájás, látászavarok, az egyes agyidegek (I, II, III, IX, XII) parézise jelentkezhet $(26,58)$. A n. facialis egyvagy kétoldali parézise a betegek kb. 30\%-ában alakul ki. A VII. agyideg intermittáló bénulása (az esetek mintegy 30\%-ában) olykor évekkel megelőzheti az ödémás jelenségeket. Az orofaciális granulomatózist (főként ha egyéb tünetekkel: arcduzzanattal, cheilitis angularissal, nyálkahártya-fekélyekkel, gingiva-hiperpláziával együtt jelentkezik) gyakran hozzák összefüggésbe Crohn-betegséggel. Kialakulása évekkel megelőzheti az ún. inflammatory bowel disease (IBD) tünetegyüttest $(27,43,65,72)$.

Tipikus megjelenési formája az ajkakon jelentkező diffúz vagy noduláris tapintatú duzzanat, leggyakrabban az alsó ajkon, néha a buccán. Ritkán a homlok, a szemhéjak és a hajas fejbőr is érintett. Az ajkak duzzanata perzisztál, makrokeilia alakul ki, az ajak berepedezett, fisszurált, vöröses-barnásan elszíneződött, hámlik.
Az esetek mintegy 20-40\%-ában a nyelv barázdált, fisszurált, a betegek egy része elveszti ízérzését, a nyálmirigyek diszfunkciója miatt xerosztómia alakul ki.

\section{Differenciáldiagnózis}

A kórkép elkülönítése fontos: szerzett vagy öröklött angioedémától, valódi Crohn-betegségtől (endoszkópia, biopszia), ritkán leprától, limfómától, sarcoidosistól, TBCtől (mellkas-RTG-PET).

Az ödémás, noduláris elváltozást mutató régiókból vett szövettani kép limfödémát, perivaszkuláris, limfocitás infiltrációt mutat.

\section{Kezelés}

A gyógyszeres kezelés alapvetően immun-moduláns szerek (NSAID, MTX, Azathioprine, Tacrolimus), tartósan alkalmazott antibiotikumok (tetracyclinek, erythromycin, ketotifen, minocillin, roxithromycin) adásából áll. Intralézionálisan adott szteroidok is hatással lehetnek (19, 23, 73, 79).

A gócosan infiltrált ajak miatt kialakult makrokeilia sebészi redukciója után, az érintett terület irradiációja, lokális szteroidok adása segíthet a recidivák kialakulásának lassításában (28).

Egyes szerzők metronidazol (24), avlosulfone (mycobaktérium ellen hatásos, hatásmechanizmusa a szulfonamidéhoz hasonló, PABA-antagonista, gátolja a fólsavszintézist, a baktériumok szaporodását) (68), sulfapyridene (PABA-antagonista), sulfasalazine (prosztaglandin-szintézis gátlása) jótékony hatásairól számolnak be.

Allergiás alapon létrejött formák az allergén kizárásával gyógyíthatók.

\section{Lupus erythematosus orális manifesztációi}

$\mathrm{Az}$ autoimmun betegségek közül jellegzetesen fénynek kitett lokalizációban jelentkeznek az erythematodes bőrtünetei. Limitált, csak bőrt érintő forma a discoid lupus erythematodes, mely társulhat belszervi érintettséggel is járó SLE-vel. Szájnyálkahártya-léziók egyébként mindkét formában előfordulhatnak, gyakorisága szisztémás lupus erythematodesben (SLE) 9-45\%ra, míg a belszervi manifesztációval nem járó krónikus cutan discoid formában (DLE) 3-20\%-ra tehető (38, 45, 66, 67).

Az ajkak érintettsége esetén DLE-ben éles szélú discoid léziók mellett akár diffúz cheilitis is felléphet, mely napfényhatásra kifejezett exacerbatiót mutat (6, 45). A típusos discoid plakkok többnyire az ajakpíron indulnak, és annak határát elmosva húzódnak rá a környező vékony bőrre vagy a mucosára $(45,67)$. Az orális mucosa DLE léziói kezdetben általában tünetmentesek, csak később, az esetleges kifekélyesedés kapcsán jelentkezhet diszkomfort, fájdalom $(6,45,57)$. Az ajkak érintettsége esetén kizárandók: kontakt cheilitis, aktinikus cheilitis, leukoplákia, lichen planus, psoriasis, erythema exsudativum multiforme, pemphigus vulgaris, illetve laphámrák $(33,45)$. 
A diagnózis felállítása a szájnyálkahártya anatómiai és funkcionális sajátosságaiból adódóan komplikáltabb: Döntően a mucosalis felszín érintettsége esetén, a pilosebaceus egység hiánya miatt a DLE-re jellemző follikuláris szarucsapok is hiányoznak; a szintén DLE-ben tipikus hegesedés és atrophia mértéke is nehezebben megítélhető a mucosa jó regenerációs hajlama miatt (45). A DLE-nek megfelelő nyálkahártya léziók klasszikus klinikai képe egy vagy több, aszimmetrikusan elhelyezkedő, élesen körülhatárolt, széli részen csipkézett, kerek vagy szabálytalan alakú plakk. A plakk erythemás centrális részén ulceratio, valamint atrophia jelentkezhet, a fehéres szabálytalan peremtől pedig sugárirányban futó fehér, keratotikus barázdák húzódhatnak. A széli részen ritkábban teleangiectasiákat találunk $(6,33,45,57,67)$. Olykor a klasszikus megjelenéstôl eltérôen, keratotikus barázdákkal övezett linearis ulceratiók láthatók. A kifejezetten vaskos, keratotikus réteggel fedett fehér léziók a krónikus cutan lupus ritkább, verrucosus formájára utalnak (45).

Lupus erythematosus (LE) esetében régóta ismert, hogy a klasszikus bőrtünetek nem ritkán párosulnak a nyálkahártyák, azon belül is elsôdlegesen az orális mucosa érintettségével. A tünetek a szájüregben bárhol kialakulhatnak, leggyakrabban azonban a kemény szájpad és a buccák nyálkahártyáján észlelhetôk $(5,33,45,57)$. Gyakori továbbá az ajkak (elsôsorban az alsó ajak) érintettsége (6, 33, 45). Az ajak- és szájnyálkahártya-tünetek megjelenésének kedvezőtlen klinikai kimenetelre utaló prognosztikai szerepe felvetôdött, ám mindmáig nem egyértelmúen bizonyított $(6,45,67)$.

A diagnózis a hisztopatológiai kép valamint a direkt immunfluoreszcens vizsgálatok eredménye alapján állítható fel. A szövettani képre jellemző elváltozások: hyperkeratosis; alternáló epitheliális hyperplasia és atrophia; bazális membrán vacuoláris degenerációja; mély diffúz/fokális/perivaszkuláris lymphocytás infiltrátum; vaskos, juxtaepithelialis PAS-pozitív depozitumok (67). Karjalainen és mtsai. összehasonlították az orális DLE, illetve a differenciáldiagnosztikai szempontból kulcsfontosságú orális lichen planus és lichenoid gyógyszerreakciók alapvető szövettani sajátosságait (25). A direkt immunfluoreszcens vizsgálat orális DLE-ben az egyéb bőrterületekhez hasonlóan pozitív, lineáris/granuláris immunglobulin ( $\mathrm{IgA} / \mathrm{IgM} / \mathrm{IgG})$ és komplement lerakódás figyelhetô meg a bazálmembrán mentén $(6,33,66,67)$. A patogenezis molekuláris hátterében immunhisztokémiai vizsgálattal a T-lymphocyták (fóként CD3+, CD4+ helper T-sejtek) meghatározó szerepét igazolták, melyek a B-lymphocyták antitesttermelését elősegítve fejtik ki gyulladást provokáló hatásukat (33). A gyulladásos citokinek közül mind a Th1 (TNF- $\alpha$, IFN- $\gamma$ ), mind a Th2 (IL-10) citokinek kimutathatók a léziókban (38).

Terápiaként elsôsorban lokálisan alkalmazott szteroidkészítmények és tacrolimus, valamint szisztémásan adott hydroxychloroquin, esetleg thalidomid jön szóba. Az esetleges malignus transzformáció veszélye miatt a betegek hosszú távú, rendszeres követése indokolt.

\section{Atópiás és allergiás kontakt cheilitis}

Míg az akut cheilitises folyamatoknál elsôsorban infekciózus, vagy akut allergiás eredetre kell gondolnunk, az ajak bőrének krónikus gyulladását leggyakrabban irritatív vagy késôi típusú kontakt szenzibilizációs folyamatok okozzák, igen gyakran atópiás prediszpozícióval. Tünetek szempontjából akut esetben az erythema és az oedema dominál, míg hosszan fennálló folyamatoknál az ajkak berepedezése, szárazsága, erythemája és hámlás jellemző. A diagnózis klinikai, allergiás eredetet epicutan tesztek segítségével igazolhatunk (18).

Az atópiás dermatitis ún „minor” tünetei -diagnosztikus kritériumai- között tartjuk számon a krónikus cheilitist, mely atópiás gyermekeknél és felnőtteknél egyaránt megfigyelhetô. A cheilitises betegek 10-20\%-ánál bizonyítható atópiás hajlam. A nők nagyobb arányban érintettek, mint a férfiak, melynek hátterében részben a nôk által nagyobb arányban használt kozmetikumok irritatív, illetve allergizáló hatása áll, másrészt a nők hamarabb fordulnak orvoshoz enyhébb bőrtünetekkel is. Az atópiás cheilitist angulus infectiosus oris, bakteriális felülfertőződés is kísérheti. A folyamat alapvetően irritatív etiológiájú, minimális traumák is ronthatják, de kontakt szenzibilizációval is szövődhet. A tünetek kialakulásában az alapbetegségre jellemző bőrszárazság miatt kialakult rossz szokás, az ajkak állandó nyalogatása, nedvesítése is szerepet játszhat. Terápiájának alapja az ajak bőrének hidratálása, zsírozása és a kísérő szuperinfekciók kezelése (51, 61, 86).

Allergiás kontakt cheilitist felnôtteknél gyakrabban észlelhetünk, mint gyermekeknél. Hátterében leggyakrabban igazolt, releváns allergének az illatanyagok, a perubalzsam és a nikkel. Ezek elsősorban arc- és szájápolókkal (szájfények, rúzsok, arckrémek), szájhigiénés termékekkel (fogkrém, szájvíz) kapcsolhatók össze, de a kézen illetve körmön használt dekorkozmetikumok (körömlakk, múkörmök) összetevői és ritkán élelmiszerek is provokálhatják a tüneteket.

A fogászati kezelések során használt anyagokkal kapcsolatban kialakuló cheilitis esetén gyakran tapasztalunk szájnyálkahártya tüneteket is. A nikkel a leggyakrabban szenzibilizáló fogászati fém, fogszabályozó készülékek, fogpótlások, ötvözetek anyagaként válthat ki túlérzékenységi reakciót. Nikkel-allergia esetén társult palládium- és réz- szenzibilizációt is megfigyeltek. Jellegzetes panaszok esetén a fogászati anyagok közül az egyéb fémek, az akrilátok, egyes szájfertôtlenítőkben, lenyomati anyagokban és cementekben megtalálható illatanyagok (eugenol) túlérzékenyítô hatására is gondolni kell.

Krónikusan fennálló cheilitis esetén mindenképpen javasolt a környezeti standard kontakt epicutan sor tesztelése. Megfelelő anamnesztikus adatok birtokában és szájnyálkahártya tünetek esetén a fogászati sor vizsgálata szükséges. Allergiás eredet esetén a terápia lényege a kimutatott allergén kerülése illetve a szájból történő eltávolítása $(51,61,71)$. 


\section{Összefoglalás}

A cheilitisek leggyakrabban fizikokémiai okok, allergének miatt alakulnak ki. Tünettanuk, lefolyásuk igen változatos, a klinikus számára sokszor nehezen felismerhető, megítélhető. A különféle klinikai formák gyógyulási és malignizációs hajlama eltérô.

Mivel a rosszindulatú ajakdaganatok döntő többségét a cheilitis valamelyik formája előzi meg (okozza), különösen fontos ezen kórképek ismerete, egymástól való elkülönítése.

\section{IRODALOM}

1. Armenores $P$. és mtsai.: Treatment of actinic cheilitis with the Er:YAG laser. J Am Acad Dermatol (2010) 63, 642-646.

2. Berking C. és mtsai.: The efficacy of photodynamic therapy in actinic cheilitis of the lower lip: a prospective study of 15 patients. Dermatol Surg. (2007) 33, 825-830.

3. Blinder D., Yahatom R., Taicher S.: Oral manifestations of sarcoidosis. Oral Surg Oral Med Oral Pathol Oral Radiol Endod (1997) 83, 458-461.

4. Bovenschen H. J.: Novel Treatment for Cheilitis Glandularis: Letters to the Editor Acta Derm Venereol (2005) 89, 99-100.

5. Butt F. M. és mtsai.: Cheilitis glandularis progressing to squamous cell carcinoma in an HIV-infected patient: case report. East Afr Med J (2007) 84, 595-598.

6. Callen J. P.: Oral manifestations of collagen vascular disease. Semin Cutan Med Surg (1997) 16, 323-327.

7. Carrington P. R., Horn T. D.: Cheilitis glandularis: a clinical marker for both malignancy and/or severe inflammatory disease of the oral cavity. J Am Acad Dermatol (2006) 54, 336-337.

8. Cataldo E., Doku H. C.: Solar cheilitis. J Dermatol Surg Oncol (1981) 7, 989-995.

9. Cavalcante A. S. R., Anbinder A. L., Carvalho Y. R.: Actinic cheilitis: Clinical and histological features. J Oral Maxillofac Surg (2008) 66, 498-503.

10. Chiller K. G. és mtsai.: Cancer of the skin. In: Kasper DL et al., eds. Harrisons Principles of Internal Medicine. 16th ed. New York: McGraw-Hill; (2005) 497-503.

11. Cockerell C. J.: Pathology and pathobiology of the actinic (solar) keratosis. Br J Dermatol (2003) 149 (Suppl 66), 34-36.

12. Dhanapal $R$. és mtsai.: Maxillary double lip and cheilitis glandularis: An unusual occurence. J Oral Maxillofac Pathol (2007) $11,35-37$.

13. Dufresne R. G. és mtsai.: Dermabrasion for actinic cheilitis. Dermatol Surg (2008) 34, 848-850.

14. Erkek E. és mtsai.: A case of cheilitis glandularis superimposed on oral lichen planus: successful palliative treatment with topical tacrolimus and pimecrolimus. J Eur Acad Dermatol (2007) 21 , 999-1000.

15. Fecker L. F. és mtsai.: The role of apoptosis in the therapy and prophylaxis of epithelial tumours by nonsteroidal antiinflammatory drugs. (NSAIDs). Br J Dermatol (2007) 156 (Suppl 3), 25-33.

16. Ficarra G. és mtsai.: Oral Crohn's disease and pyostomatitis vegetans. An unusual association. Oral Surg Oral Med Oral Pathol (1993) 75, 220-224.

17. Goette D. K.: Topical chemotherapy with 5-fluorouracil. J Am Acad Dermatol (1981) 4, 633-649.

18. Harangi F., Schneider I., Sebók B.: Atópiás dermatitis (2009) Medicina Kiadó, Budapest, ISBN: 9789632261577

19. Hazey M. A., Van Norman A. J., Armistead D. L.: MelkerssonRosenthal Syndrome with migraine-like headaches treated with minocycline: a case report and review of the literature. $\mathrm{W} \mathrm{V}$ Med J (2009) 105, 15-17.

20. Hillen U., Franckson T., Goos M.: Cheilitis glandularis: a case report. Acta Derm Venereol (2004) 84, 77-79.

21. Huber M. A., Terezhalmy G. T.: The patient with actinic cheilitis. Gen Dent (2006) 54, 274-282.
22. Ishida C. E., Ramos-e-Silva M.: Cryosurgery in oral lesions. Int J Dermatol (1998) 37, 283-285.

23. Ishiguro E. és mtsai.: Successful treatment of granulomatous cheilitis with roxithromycin. J Dermatol (2008) 35, 598-600.

24. Kano $Y$. és mtsai.: Treatment of recalcitrant cheilitis granulomatosa with metronidazole. J Am Acad Dermatol (1992) 27, 629-630.

25. Karjalainen T. K., Tomich C. E.: A histopathologic study of oral mucosal lupus erythematosus. Oral Surg Oral Med Oral Pathol (1989) 67, 547-554.

26. Khandpur S., Malhotra A. K., Khanna N.: Melkersson-Rosenthal syndrome with diffuse facial swelling and multiple cranial nerve palsies. J Dermatol (2006) 33, 411-414.

27. Khouri J. M., Bohane T. D., Day A. S.: Is orofacial granulomatosis in children a feature of Crohn's disease? Acta Paediatr (2005) 94, 501-514.

28. Kruse-Losler B. és mtsai.: Surgical treatment of persistent macrocheilia in patients with Melkersson-Rosenthal syndrome and cheilitis granulomatosa. Arch Dermatol (2005) 141, 10851091

29. Leao J. C. és mtsai.: Cheilitis glandularis: An unusual presentation in a patient with HIV infection. Oral Surg Oral Med Oral Pathol Oral Radiol Endod (2003) 95, 142-144.

30. Lederman D. A.: Suppurative stomatitis glandularis. Oral Surg Oral Med Oral Pathol (1994) 78, 319-322.

31. Leffel D. L.: The scientific basis of skin cancer. J Am Acad Dermatol (2000) 42, 518-522.

32. Lima G. S. mtsai.: Diclofenac in hyaluronic acid gel: an alternative treatment for actinic cheilitis. J Appl Oral Sci (2010) $18,533-537$.

33. Lourenco $S$. V. és mtsai.: Lupus erythematosus: clinical and histopathological study of oral manifestations and immunohistochemical profile of the inflammatory infiltrate. J Cutan Pathol (2007) 34, 558-564.

34. Lourenco $S$. V. és mtsai.: Cheilitis glandularis in albinos: a report of two cases and review of histopathological findings after therapeutic vermilionectomy. J Eur Acad Dermatol Venereol (2007) $21,1265-1267$.

35. Lund H. Z.: How often does squamous carcinoma of the skin metastatize? Arch Dermatol (1965) 92, 635-637.

36. Main J. H.: Actinic cheilitis and carcinoma of the lip. J Can Dent Assoc (1994) 60, 113-116.

37. Markopoulos A., Albanidou-Farmaki E., Kayavis I.: Actinic cheilitis: clinical and pathologic characteristics in 65 cases. Oral Dis (2004) 10, 212-216.

38. Marques E. R. és mtsai.: Oral lesions in lupus erythematosuscytokines profiles of inflammatory infiltrate. J Cutan Pathol (2010) 37, 439-445.

39. Matsumura Y., Ananthaswamy H. N.: Toxic effects of ultraviolet irradiation on the skin. Toxicol Appl Pharmacol (2004) 195, 298-308.

40. McKenna K. E., Walsh M. Y., Burrows D.: The MelkerssonRosenthal syndrome and food additive hypersensitivity. $\mathrm{Br} \mathrm{J}$ Dermatol (1994) 131, 921-922.

41. Morales $C$. és mtsai.: Immunological study of MelkerssonRosenthal syndrome. Lack of response to food additive challenge. Clin Exp Allergy (1995) 25, 260-264.

42. Musa N. J. és mtsai.: Multiple suppurative cystic lesions of the lips and buccal mucosa: a case of suppurative stomatitis glandularis. Oral Surg Oral Med Oral Pathol Oral Radiol Endod (2005) 99, 175-179.

43. Narbutt P., Dziki A.: Melkersson-Rosenthal syndrome as an early manifestation of Crohn's disease. Colorectal Dis (2005) 7, 420-421.

44. Nico M. M. S., Rivitti E. A., Laurenco S. V.: Actinic cheilitis: histologic study of the entire vermillon and comparison with previous biopsy. J Cutan Pathol (2007) 34, 309-314.

45. Nico M. M. S. és mtsai.: Oral lesions in lupus erythematosus: correlation with cutaneous lesions. Eur J Dermatol (2008) 18, 376-381.

46. Nico M. M. S., Nakano de Melo J., Lourenco S. V.: Cheilitis glandularis: A clinicopathological study in 22 patients. J Am Acad Dermatol (2010) 62, 233-238. 
47. Orenstein A. és mtsai.: A new modality in the treatment of actinic cheilitis using the Er:YAG laser. J Cosmet Laser Ther (2007) 9, 23-25.

48. Parmar R. C., Muranjan M. N.: A newly recognized syndrome with double upper and lower lip, hypertelorism, eyelid ptosis, blepharophimosis, and third finger clinodactyly. Am J Med Genet A (2004) 124, 200-201.

49. Picascia D. D., Robinson J. K.: Actinic cheilitis: A review of the etiology, differential diagnosis, and treatment. J Am Acad Dermatol (1987) 17, 255-263.

50. Puente J. J., Acevedo A.: Queilitis glandularis. Rev Med Latinoam (1927) 12, 671-679.

51. Pugliarello S. és mtsai.: Phenotypes of atopic dermatitis JDDG (2011) 9, 12-20.

52. Rada D. C., Koranda F. C., Katz F. S.: Cheilitis glandularis - a disorder of ductal ectasia. J Dermatol Surg Oncol (1985) 11, 372-375.

53. Reiter S. és mtsai.: Cheilitis glandularis: clinico-histopathological diagnostic criteria. Oral Dis (2011) 17, 335-339.

54. Robinson J. K.: Actinic cheilitis. A prospective study comparing four treatment methods. Arch Otolaryngol Head Neck Surg (1989) $115,848-852$.

55. Rossi R., Mor M., Lott T.: Actinic keratosis. Int J Dermatol (2007) 46, 895-904.

56. Rossoe E. W. T. és mtsai.: Actinic cheilitis: aesthetic and functional comparative evaluation of vermilionectomy using the classic and W-plasty techniques. An Bras Dermatol (2011) 86, 65-73.

57. Rothfield N., Sontheimer R. D., Bernstein M.: Lupus erythematosus: systemic and cutaneous manifestations. Clin Dermatol (2006) 24, 348-362.

58. Saito T. és mtsai.: Melkersson-Rosenthal syndrome: distal facial nerve branch palsies, masseter myopathy and corticosteroid treatment. Fukushima J Med Sci (1994) 40, 39-44.

59. Savage N. W., McKay C., Faulkner: Actinic cheilitis in dental practice. Aust Dent J (2010) 55, Suppl.1., 78-84.

60. Scheinberg R. S.: Carbon Dioxide Laser Treatment of Actinic Cheilitis West J Med (1992) 156, 192-193.

61. Schena D., Fantuzzi F., Girolomoni G.: Contact allergy in chronic eczematous lip dermatitis Eur J Dermatol (2008) 18, 688-692.

62. Scheunemann H., Greither A., Hornstein O.: Krankheiten der Mundschleimhaut un der Lippen. Urban \& Schwarzenberg, München-Berlin-Wien, 1966.

63. Schwartz R. A. és mtsai.: Actinic keratosis: an occupational and evironmental disorder. Eur Acad Dermatol Venerol (2008) 22 606-615.

64. Schweich L.: Cheilitis glandularis simplex (Puente and Acevedo). Arch Dermatol (1964) 89, 301-302.

65. Scully C. és mtsai.: Crohn's disease of the mouth: an indicator of intestinal involvement. Gut (1982) 23, 198-201.

66. Serpico R. és mtsai.: Report of a case of discoid lupus erythematosus localised to the oral cavity: immunofluorescence findings. Int J Immunopathol Pharmacol (2007) 20, 651-653.
67. Sharma P. és mtsai.: Oral discoid lupus erythematosus: histopathologic diagnosis at the light microscopic level. Int $\mathrm{J}$ Oral-Med Sci (2009) 8, 107-111.

68. Sobjanek M. és mtsai.: Successful treatment of MelkerssonRosenthal syndrome with dapsone and triamcinolone injections. J Eur Acad Dermatol Venereol (2008) 22, 1028-1029; author reply $1027-1028$.

69. Stanley R. J., Roenigk R. J.: Actinic cheilitis: Treatment with the carbon dioxide laser. Mayo Clin Proc (1988) 63, 230-235.

70. Stoopler E. T. és mtsai.: Cheilitis glandularis: an unusual histopathologic presentation. Oral Surg Oral Med Oral Pathol Oral Radiol Endod (2003) 95, 312-317.

71. Temesvári E.: Fogászati kontakt allergének. Bőrgyógyászati és Venerológiai Szemle (2004) 80, 53-61.

72. Tilakaratne W. M., Freysdottir J., Fortune F.: Orofacial granulomatosis: review on aetiology and pathogenesis. J Oral Pathol Med (2008) 37, 191-195.

73. Tonkovic-Capin V. és mtsai.: Cutaneous Crohn's disease mimicking Melkersson-Rosenthal syndrome: treatment with methotrexate. J Eur Acad Dermatol Venereol (2006) 20, 449452.

74. Torma H., Berne B., Vahlquist A.: UV irradiation and topical vitamin A modulate retinol esterification in hairless mouse epidermis. Acta Derm Venerol (1988) 68, 291-299.

75. von Volkmann R.: Einige Fälle von Cheilitis Glandularis Apostematosa (Myxadenitis Labialis). Virchows Arch Pathol Anat (1870) 50, 142-144.

76. Weedon D.: Weedon's skin pathology. 3rd ed. Churchill Livingstone Edinburgh, (2010) 314-342.

77. Weir T. W., Johnson W. C.: Cheilitis glandularis. Arch Dermatol (1971) 103, 433-437.

78. Williams A. J., Wray D., Ferguson A.: The clinical entity of orofacial Crohn's disease. Q J Med (1991) 79, 451-458.

79. Williams P. M., Greenberg M. S.: Management of cheilitis granulomatosa. Oral Surg Oral Med Oral Pathol (1991) 72, 436439.

80. Winchester L. és mtsai.: Cheilitis glandularis: a case affecting the upper lip. Oral Surg Oral Med Oral Pathol (1986) 62, 654656.

81. Wood N. H. és mtsai.: Actinic cheilitis: A case report and a review of the literature. Eur J Dent (2011) 5, 101-106.

82. Wong G. A., Shear N. H.: Melkersson-Rosenthal syndrome associated with allergic contact dermatitis from octyl and dodecyl gallates. Contact Dermatitis (2003) 49, 266-267.

83. Yacobi R., Brown D. A.: Cheilitis glandularis: a pediatric case report. J Am Dent Assoc (1989) 118, 317-318.

84. Yuka H., Yoshikazu M., Toshiyuki Y.: Successful treatment of plasma cell cheilitis with topical tacrolimus: Report of two cases. Dermatol Online J (2011) 17, 6.

85. Zelickson B. D., Roenigk R. K.: Actinic cheilitis. Treatment with the carbon dioxide Laser. Cancer (1990) 65, 1307-1311.

86. Zug K. A., Kornik R., Belsito D. V.: Patch testig North American lip dermatitis patients: data from the North American Contact Dermatitis Group, 2001 to 2004. Dermatitis (2008) 19, 202-208. 